\title{
HUBUNGAN PRAKTIK KULIAH LAPANGAN TERHADAP PEMBENTUKAN KOMPETENSI KEPRIBADIAN CALON GURU
}

\author{
Eka Nurdiana ${ }^{1}$, Muhammad Zid ${ }^{2}$, Aris Munandar ${ }^{3}$ \\ 1,2,3Program Studi Pendidikan Geografi FIS UNJ \\ Jl. Rawamangun Muka, Pulo Gadung, Jakarta Timur, Jakarta, 13220, Indonesia \\ Email: ekanrdn@gmail.com
}

\begin{abstract}
Abstrak
Penelitian ini bertujuan untuk mengetahui kontribusi Praktik Kuliah Lapangan terhadap Pembentukan Kompetensi Kepribadian Calon Guru di Program Studi Pendidikan Geografi, Fakultas Ilmu Sosial, Universitas Negeri Jakarta. Penelitian ini dilakukan dari bulan Juli hingga November 2018. Metode pengambilan sampel adalah purposive sampling. Penelitian ini dilakukan di tiga (3) lokasi, lokasi 1 geografi fisik di Desa Candirenggo-Kebumen, lokasi 2 geografi dan pemetaan sosial ekonomi di Desa Candi-Semarang, dan lokasi 3 Terpadu di Desa Plajan-Jepara. Populasi dan sampel dalam penelitian ini adalah siswa Program Studi Pendidikan Geografi untuk 2017, 2016, dan 2015 dengan total 60 siswa sebagai responden. Hasil penelitian ini, yaitu, korelasi antara variabel penilaian pada PKL meliputi: penilaian sikap, kinerja alat, kinerja presentasi, proyek, dan portofolio dengan variabel kompetensi kepribadian, (1) variabel penilaian proyek memiliki kekuatan hubungan yang lebih besar dengan variabel kompetensi kepribadian daripada penilaian orang lain; (2) ada hubungan terbalik antara penilaian sikap dan penilaian portofolio dengan kompetensi kepribadian. Dengan demikian, ini menyatakan bahwa penilaian sikap tidak digunakan karena dibentuk sebagai efek samping dari setiap kegiatan secara tidak langsung dan penilaian portofolio direvisi karena masing-masing kekuatan menghasilkan produk dari hasil yang berbeda.
\end{abstract}

Kata Kunci: Praktik Kuliah Lapangan, Kompetensi Kepribadian, Calon Guru

\begin{abstract}
This study aims to determine the contribution of Praktik Kuliah Lapangan to the Formation of Personality Prospective Teacher Competencies in Geography Education Study Program, Faculty of Social Sciences, Jakarta State University. This research was conducted from July to November 2018. The sampling method was purposive sampling. This research was conducted in three (3) locations, location 1 physical geography in Desa Candirenggo-Kebumen, location 2 social economic geography and mapping in Desa Candi-Semarang, and location 3 Integrated in Desa Plajan-Jepara. The population and sample in this study were students Geography Education Study Program for 2017, 2016, and 2015 with a total of 60 students as respondents. The results of this study, namely, the correlation between the assessment variables on street vendors include: assessment of attitudes, tool performance, presentation performance, projects, and portfolios with personality competency variables, (1) project appraisal variables have greater relationship strength with personality competency variables than assessment others; (2) there is an inverse relationship between attitude assessment and portfolio assessment with personality competencies. Thus, this states that the attitude assessment is not used because it is formed as a side effect of each activity indirectly and the assessment of the portfolio is revised because each force produces products of different results.
\end{abstract}

Keywords: Praktik Kuliah Lapangan, Personality Competence, Teacher Candidates. 


\section{PENDAHULUAN}

Pendidikan menjadi salah satu kebutuhan yang penting bagi manusia. Setiap orang memiliki hak untuk memperoleh pendidikan yang bermutu demi keberlangsungan proses belajarnya. Sejak masih kecil, pada dasarnya manusia sudah melakukan kegiatan belajar. Mulai dari bayi yang begitu banyak melalui proses belajar seperti belajar merangkak, berjalan, maupun bicara. Sehingga, manusia dapat melalukan sesuatu hal perlu melalui proses yang namanya belajar. Ketika manusia melalui proses belajar, memerlukan wadah yaitu pendidikan.

Menurut Undang-undang Republik Indonesia Nomor 20 Tahun 2003 tentang Sistem Pendidikan Nasional, "Pendidikan adalah usaha sadar dan terencana untuk mewujudkan suasana belajar dan proses pembelajaran agar peserta didik secara aktif mengembangkan potensi dirinya untuk memiliki kekuatan spiritual keagamaan, pengendalian diri, kepribadian, kecerdasan, akhlak mulia, serta keterampilan yang diperlukan dirinya, masyarakat, bangsa dan negara" (UU Sisdiknas, 2003). Pendidikan merupakan salah satu faktor penting yang dapat digunakan merealisasi bakat-bakat yang dibawa manusia sejak lahir, sehingga manusia mempunyai keterampilan yang dapat digunakan untuk menghidupi dirinya. Melalui pendidikan, setiap manusia dapat melakukan proses belajar dengan mengembangkan bakat lahiriyahnya. Sehingga, pendidikan menjadi jendela untuk melihat begitu luasnya kehidupan.

Ilmu dan pengetahuan yang didapat dalam pembelajaran luar kelas tidak hanya selalu tentang teori yang didapat dari pengajar. Boleh jadi, ketika pembelajaran di luar kelas dilakukan, barulah mereka mendapati sesuatu hal yang belum mereka ketahui. Pengetahuan baru akan mereka dapati setelah mereka amati atau menjelajahi lingkungan secara langsung. Kondisi seperti inilah, yang dapat membentuk suatu keterampilan dan sikap mereka. Dengan begitu, lingkungan luar sangat berpengaruh pada perkembangan pengetahuan.

Seperti pada program studi pendidikan geografi. Secara umum, menurut Hamalik (2008) matakuliah dibagi menjadi: 1) Mata Kuliah Dasar Kependidikan (MKDK), 2) Mata Kuliah Proses Belajar Mengajar (MKPBM), 3) Program Pendidikan Disiplin Ilmu sesuai dengan jurusan, 4) Program Mata Kuliah Dasar Umum (MKDU). Salah satu program pendidikan disiplin ilmu yang khas bagi pendidikan geografi yaitu kegiatan fieldstudy/Praktik Kuliah Lapangan. PKL ini menjadi ciri khas dibanding prodi lain, karna geografi memiliki kajian yang sangat dekat dengan interaksi lingkungan/alam.

Praktik Kuliah Lapangan seperti yang dilakukan mahasiswa pendidikan geografi merupakan pengajaran di luar kelas guna mendapatkan dan menggali materi yang bersumber pada masyarakat. Praktik Kuliah Lapangan adalah salah satu program kegiatan akademik di Program Studi Pendidikan Geografi sebagai realisasi dari tuntutan tujuan pendidikan nasional dan Tri Darma Perguruan Tinggi (Hayati, 2005).

Sebagai calon pendidik, mahasiswa pendidikan geografi dituntut untuk melatih kompetensi-kompetensi guru sejak kuliah. Untuk itu, dilaksanakannya Praktik Kuliah Lapangan ini, mahasiswa dapat belajar lebih mengenal keadaan lingkungan secara langsung. Maka dari itu, mahasiswa perlu mempersiapkan mental untuk berhadapan langsung dengan kondisi dan suasana di lingkungan baru.

Dengan demikian, mahasiswa dituntut untuk lebih interaktif dengan lingkungan alam dan sosial dalam PKL, yang berpotensi mempengaruhi karakter mahasiswa. Hal ini menjadi menarik untuk dikaji. Maka dari itu, penulis tertarik untuk meneliti tentang kontribusi Praktik Kuliah Lapangan terhadap pembentukan 
kompetensi kepribadian calon guru di Program Studi Pendidikan Geografi Fakultas Ilmu Sosial Universitas Negeri Jakarta.

\section{METODE PENELITIAN}

Penelitian ini bertujuan untuk mengetahui kontribusi Praktik Kuliah Lapangan terhadap Pembentukan Kompetensi Kepribadian Calon Guru di Program Studi Pendidikan Geografi Fakultas Ilmu Sosial Universitas Negeri Jakarta. Penelitian ini dilaksanakan pada Bulan Juli sampai dengan November 2018. Metode pengambilan sampel dengan purposive sampling. Penelitian ini dilakukan di tiga (3) lokasi, lokasi 1 yaitu PKL geografi fisik di Desa Candirenggo-Kebumen, lokasi 2 yaitu PKL geografi sosial ekonomi dan pemetaan di Desa Candi-Semarang, dan lokasi 3 yaitu PKL Terpadu di Desa PlajanJepara. Populasi dalam penelitian ini adalah mahasiswa yang mengikuti Praktik Kuliah Lapangan Program Studi Pendidikan Geografi Angkatan 2017, 2016, dan 2015. Penelitian ini dilaksanakan dengan mengambil responden sebanyak 10 mahasiswa yang menggunakan alat-alat lapangan dan 10 mahasiswa yang menggunakan instrumen/kusioner lapangan pada setiap angkatan dengan total 60 mahasiswa sebagai responden. Penelitian ini menggunakan metode deskriptif kuantitatif dengan pendekatan expost facto yaitu di mana variabel-variabel bebas telah terjadi ketika peneliti mulai mengamati variabel terikat dalam suatu penelitian. Pada penelititian ini keterikatan variabel $X$ mengenai PKL dan variabel $Y$ kepribadian telah terjadi secara alami dan peneliti ingin melacak kembali. Instrumen penelitian yang digunakan berupa kuesioner tertutup.

\section{HASIL DAN PEMBAHASAN}

Kompetensi Kepribadian merupakan kemampuan personalitas, jati diri sebagai seorang tenaga pendidik yang menjadi pantauan bagi peserta didik. Kompetensi inilah yang selalu menggambarkan prinsip bahwasannya guru adalah sosok yang patut digugu dan ditiru. Dengan kata lain, guru menjadi suri teladan bagi peserta didik atau guru sebagai sumber dasar bagi peserta didik. Secara khusus kompetensi kepribadian terbagi menjadi lima indikator yaitu kepribadian yang mantap dan stabil, dewasa, arif dan bijaksana, menjadi teladan dan memiliki jiwa yang berwibawa, serta memiliki akhlah mulia. Selanjutnya, kelima indikator tersebut memiliki makna yaitu berjiwa pendidik dan bertindak sesuai dengan norma agama, hukum, sosial, dan kebudayaan nasional Indonesia, tampil sebagai pribadi yang jujur, berakhlak mulia, dan menjadi teladan bagi peserta didik dan masyarakat, tampil sebagai pribadi yang mantap, dewasa, stabil dan berwibawa, menunjukan etos kerja, tanggung jawab, rasa bangga sebagai tenaga pendidik dan rasa percaya diri.

Progran Studi Pendidikan Geografi merupakan mahasiswa yang belajar pada bidang ilmu geografi yang diarahkan sebagai tenaga pendidik. Seperti yang sudah dituliskan pada deskripsi matakuliah pendidikan geografi, bahwasannya pendidikan geografi memiliki matakuliah bidang studi dan keahlian penunjang yang salah satunya matakuliah Praktik Kuliah Lapangan. Dengan demikian, bisa kita lihat seberapa besar kontribusi matakulaih PKL ini terhadap mahasiswa Pendidikan Geografi sebagai calon guru terutama pada kompetensi keribadian di atas.

$$
\text { Setelah mendapatkan data hasil }
$$
penelitian mengunakan SPSS 22.0, selanjutnya akan dibahas mengenai terkait Variabel Sikap (X1), Kinerja Alat (X2), Kinerja Presentasi (X3), Proyek (X4) dan Portofolio (X5), dengan Variabel Kepribadian (Y) menggunakan Rank Spearman, sehingga kita mengetahui keterkaitan kontribusi penilaian pada PKL 
dengan pembentukan kompetensi kepribadian calon guru.

peneliti akan melihat penilaian pada

PKL Program Studi Pendidikan Geografi
Fakultas Ilmu Sosial Universitas Negeri Jakarta yang lebih berpengaruh terhadap pembentukan kompetensi kepribadian pada calon guru.

Tabel 1. Hasil Uji Korelasi

\begin{tabular}{|c|c|c|c|c|c|}
\hline $\begin{array}{c}\text { Korelasi } \\
\text { dengan } \\
\text { Variabel Y }\end{array}$ & $\begin{array}{l}\text { Kekuatan } \\
\text { Hubungan }\end{array}$ & $\begin{array}{c}\text { Persentase } \\
(\%)\end{array}$ & $\begin{array}{l}\text { Signifikansi } \\
\text { Hubungan }\end{array}$ & $\begin{array}{c}\text { Arah } \\
\text { Hubungan }\end{array}$ & $\begin{array}{c}\text { Kriteria } \\
\text { Hubungan }\end{array}$ \\
\hline $\begin{array}{l}\text { Penilaian } \\
\text { Sikap (X1) }\end{array}$ & $-0,182$ & 18,2 & 0,165 & Negatif & $\begin{array}{l}\text { Sangat } \\
\text { rendah }\end{array}$ \\
\hline $\begin{array}{l}\text { Penilaian } \\
\text { Kinerja Alat } \\
\text { (X2) }\end{array}$ & 0,171 & 17,1 & 0,191 & Positif & $\begin{array}{l}\text { Sangat } \\
\text { rendah }\end{array}$ \\
\hline $\begin{array}{c}\text { Penilaian } \\
\text { Kinerja }\end{array}$ & 0,108 & 10,8 & 0,412 & Positif & $\begin{array}{l}\text { Sangat } \\
\text { rendah }\end{array}$ \\
\hline $\begin{array}{c}\text { Presentasi (X3) } \\
\text { Penilaian } \\
\text { Proyek (X4) }\end{array}$ & 0,332 & 33,2 & 0,010 & Positif & Rendah \\
\hline $\begin{array}{c}\text { Penilaian } \\
\text { Portofolio (X5) }\end{array}$ & $-0,137$ & 13,7 & 0,297 & Negatif & $\begin{array}{l}\text { Sangat } \\
\text { rendah }\end{array}$ \\
\hline
\end{tabular}

Sumber: Hasil Penelitian 2018

1. Hasil Korelasi Variabel Sikap (X1) dengan Kompetensi Kepribadian (Y)

Output perhitungan korelasi, N menunjukkan jumlah responden/sampel sebanyak 60, sedangkan tingginya korelasi ditunjukkan oleh angka -0,182. Besar korelasi yang terjadi antara kedua variabel adalah $\quad-0,184$. Sedangkan angka sig.(2tailed) adalah 0,165 lebih besar daripada batas kritis $a=0,05$, berarti tidak terdapat hubungan yang signifikan antara kedua variabel $(0,165>0,05)$. Berdasarkan hasil perhitungan yang telah dilakukan, hasil pengujian hipotesis dengan menggunakan Rank Spearman didapatkan hasil bahwa tidak terdapat hubungan yang signifikan antara penilaian sikap dengan kompetensi kepribadian, yang ditunjukkan dengan diperolehnya angka sig.(2-tailed) adalah 0,165 lebih besar daripada batas kritis $a=$ 0,05 , serta diperoleh rs $=-0,182(18,2 \%)$ yang menunjukkan besarnya kekuatan hubungan antara penilaian sikap dengan kompetensi kepribadian. Berdasarkan tabel makna korelasi rank spearman, nilai 0,182 termasuk dalam interval 0,00 - 0,19 dan tergolong kategori sangat rendah, sehingga besar korelasi yang ditunjukkan sangat rendah. Nilai rs bertanda negatif, maka nilai tersebut menunjukkan bahwa semakin tinggi penilaian sikap pada calon guru akan berbanding terbalik dengan pembentukan kompetensi kepribadian.

2. Hasil Korelasi Variabel Kinerja Alat (X2) dengan Kompetensi Kepribadian (Y)

Output perhitungan korelasi, N menunjukkan jumlah responden/sampel sebanyak 60, sedangkan tingginya korelasi ditunjukkan oleh angka 0,171. Besar korelasi yang terjadi antara kedua variabel adalah 0,171. Sedangkan angka sig.(2-tailed) adalah 0,191 lebih besar daripada batas kritis $a=$ 0,05 , berarti tidak terdapat hubungan yang signifikan antara kedua variabel $(0,191>$ $0,05)$. Berdasarkan hasil perhitungan yang telah dilakukan, hasil pengujian hipotesis dengan menggunakan Rank Spearman didapatkan hasil bahwa tidak terdapat 
hubungan yang signifikan antara penilaian Kinerja Alat dengan kompetensi kepribadian, yang ditunjukkan dengan diperolehnya angka sig.(2-tailed) adalah 0,191 lebih besar daripada batas kritis $\alpha=$ 0,05 , serta diperoleh $r s=0,171(17,1 \%)$ yang menunjukkan besarnya kekuatan hubungan antara penilaian Kinerja Alat dengan kompetensi kepribadian. Berdasarkan tabel makna korelasi rang spearman nilai 0,171 termasuk dalam interval 0,00 - 0,19 dan tergolong kategori sangat rendah, sehingga besar korelasi yang ditunjukkan sangat rendah. Nilai rs bertanda positif, maka nilai tersebut menunjukkan bahwa semakin tinggi penilaian Kinerja Alat pada calon guru maka akan berhubungan lurus dengan pembentukan kompetensi kepribadian.

3. Hasil Korelasi variabel Penilaian Kinerja Presentasi (X3) dengan Kompetensi Kepribadian (Y)

Output perhitungan korelasi, N menunjukkan jumlah responden/sampel sebanyak 60 , sedangkan tingginya korelasi ditunjukkan oleh angka 0,108. Besar korelasi yang terjadi antara kedua variabel adalah 0,108. Sedangkan angka sig.(2-tailed) adalah 0,412 lebih besar daripada batas kritis $a=$ 0,05 , berarti tidak terdapat hubungan yang signifikan antara kedua variabel $(0,412>$ $0,05)$. Berdasarkan hasil perhitungan yang telah dilakukan, hasil pengujian hipotesis dengan menggunakan Rank Spearman didapatkan hasil bahwa tidak terdapat hubungan yang signifikan antara penilaian Kinerja Presentasi dengan kompetensi kepribadian, yang ditunjukkan dengan diperolehnya angka sig.(2-tailed) adalah 0,412 lebih besar daripada batas kritis $\alpha=$ 0,05 , serta diperoleh $\mathrm{rs}=0,108(10,8 \%)$ yang menunjukkan besarnya kekuatan hubungan antara penilaian Kinerja Presentasi dengan kompetensi kepribadian. Berdasarkan tabel makna korelasi rank spearman, nilai 0,108 termasuk dalam interval 0,00 - 0,19 dan tergolong kategori sangat rendah, sehingga besar korelasi yang ditunjukkan sangat rendah. Nilai rs bertanda positif, maka nilai tersebut menunjukkan bahwa semakin tinggi penilaian Kinerja Presentasi pada calon guru akan berhubungan lurus dengan pembentukan kompetensi kepribadian.

4. Hasil Korelasi variabel Penilaian Proyek (X4) dengan Kompetensi Kepribadian (Y) Output perhitungan korelasi, N menunjukkan jumlah responden/sampel sebanyak 60 , sedangkan tingginya korelasi ditunjukkan oleh angka 0,332**. Besar korelasi yang terjadi antara kedua variabel adalah 0,332. Sedangkan angka sig.(2-tailed) adalah 0,01 lebih kecil daripada batas kritis a $=0,05$, berarti terdapat hubungan yang signifikan antara kedua variabel $(0,01>$ $0,05)$. Berdasarkan hasil perhitungan yang telah dilakukan, hasil pengujian hipotesis dengan menggunakan Rank Spearman didapatkan hasil bahwa terdapat hubungan yang signifikan antara penilaian proyek dengan kompetensi kepribadian, yang ditunjukkan dengan diperolehnya angka sig.(2-tailed) adalah 0,010 lebih kecil daripada batas kritis $\alpha=0,05$, serta diperoleh rs $=0,332(33,2 \%)$ yang menunjukkan besarnya kekuatan hubungan antara penilaian proyek dengan kompetensi kepribadian. Berdasarkan tabel makan korelasi rank spearman nilai 0,332 termasuk dalam interval 0,20 - 0,39 dan tergolong kategori rendah, sehingga besar korelasi yang ditunjukkan rendah. Nilai rs bertanda positif, maka nilai tersebut menunjukkan bahwa semakin tinggi penilaian proyek pada calon guru akan berhubungan lurus dengan pembentukan kompetensi kepribadian.

5. Hasil Korelasi variabel Penilaian Portofolio (X5) dengan Kompetensi Kepribadian (Y)

Output perhitungan korelasi, N menunjukkan jumlah responden/sampel sebanyak 60 , sedangkan tingginya korelasi ditunjukkan oleh angka -0,137. Besar korelasi yang terjadi antara kedua variabel adalah $-0,137$. Sedangkan angka sig.(2- 
tailed) adalah 0,297 lebih besar daripada batas kritis $a=0,05$, berarti tidak terdapat hubungan yang signifikan antara kedua variabel $(0,297>0,05)$. Berdasarkan hasil perhitungan yang telah dilakukan, hasil pengujian hipotesis dengan menggunakan Rank Spearman didapatkan hasil bahwa tidak terdapat hubungan yang signifikan antara penilaian portofolio dengan kompetensi kepribadian, yang ditunjukkan dengan diperolehnya angka sig.(2-tailed) adalah 0,297 lebih besar daripada batas kritis $\alpha=0,05$, serta diperoleh $r s=-0,137(13,7 \%)$ yang menunjukkan besarnya kekuatan hubungan antara penilaian portofolio dengan kompetensi kepribadian. Berdasarkan tabel makna korelasi rank spearman nilai 0,137 termasuk dalam interval 0,00 - 0,19 dan tergolong kategori sangat rendah, sehingga besar korelasi yang tunjukkan sangat rendah. Nilai rs bertanda negatif, maka nilai tersebut menunjukkan bahwa semakin tinggi penilaian portofolio pada calon guru akan berbanding terbalik dengan pembentukan kompetensi kepribadian.

Berikut ini pembahasan mengenai masing-masing variabel $\mathrm{X}$ dengan variabel Y:

1. Variabel X1 (Penilaian Sikap) dengan Variabel Y (Kompetensi Kepribadian)

Berdasarkan hasil penelitian pada hasil uji korelasi, kontribusi penilaian sikap terhadap pembentukan kompetensi calon guru sebesar $18,2 \%$. Setiap calon guru yang mendapatkan penilaian sikap hanya akan berkontribusi kecil terhadap pembentukan kompetensi calon guru. Sikap terbentuk akibat dari dampak pembelajaran secara tidak langsung (Nurturant Effect). Menurut Joyce (2009), Nurturant effects (dampak pengiring, dampak ikutan) artinya tidak secara langsung ditetapkan sebagai tujuan pembelajaran tapi penting untuk dicapai atau penting untuk dibinakan kepada anak didik. Secara umum, tujuan pembelajaran ada dua yaitu Intructional effect $\mathcal{E}$ Nurturant
Effect. Intructional effect yaitu efek yang terjadi atau terlihat secara langsung yang ingin dicapai melalui pembelajaran tertentu seperti pengetahuan dan keterampilan yang telah didapat peserta didik dari pendidik. Sedangkan Nurturant Effect yaitu tujuan pembelajaran yang lebih merupakan hasil sampingan dari hasil pembelajaran, biasanya dampak pengiring ini berkenaan dengan efek domain (nilai sikap) yang apabila peserta didik menghayati proses pembelajaran atau kegiatan. Dengan demikian, kompetensi kepribadian yang mantap dan stabil, dewasa, arif, bijaksana, serta menjadi teladan dan kepribadian yang berwibawa bila dilihat dari kegiatan PKL bisa saja terbentuk dari masing-masing mahasiswa atau calon guru. Namun, terbentuknya sikap setiap individu yang dilakukan pada saat PKL bila dikaitkan dengan indikator kompetensi kepribadian calon guru, dampaknya akan terjadi apabila mahasiswa atau calon guru yang menghayati proses PKL. sehingga, penilaian sikap pada Praktik Kuliah Lapangan di Program Studi Pendidikan Geografi tidak dapat digunakan sebagai penilaian dalam pembentukan kompetensi kepribadian calon guru secara langsung.

2. Variabel X2 (Penilaian Kinerja Alat) dengan Variabel Y (Kompetensi Kepribadian)

Berdasarkan hasil penelitian pada hasil uji korelasi, kontribusi penilaian kinerja alat dengan pembentukan kompetensi kepribadian calon guru sebesar $17,1 \%$. Setiap calon guru yang mendapatkan penilaian Kinerja Alat, akan berkontribusi terhadap pembentukan kompetensi calon guru. Dalam RPS matakuliah PKL Prodi Pendidikan Geografi UNJ (2017), penggunaan Kinerja Alat PKL merupakan suatu keterampilan khusus yang dimiliki oleh mahasiswa Pendidikan Geografi atau calon guru Geografi, sehingga berkaitan dengan indikator kompetensi kepribadian yang berwibawa, dewasa dan arif yaitu 
bertindak profesional, memiliki etos kerja yang tinggi, serta bertindak yang bermanfaat. Ketika seorang calon guru memiliki kepribadian yang berwibawa, secara tidak langsung nilai-nilai kepribadian dan karakter yang ditunjukan menjadi daya tarik peserta didik untuk menjadi pengajar atau pendidik sebagai cerminan pada dirinya, sehingga pada matapelajaran geografi yang kita ketahui terdapat praktik lapangan, akan lebih terlihat menyenangkan apabila pendidik itu sendiri memiliki kepribadian yang berwibawa ketika mempraktikan langsung secara profesional alat-alat penunjang matapelajaran geografi pada pembelajaran praktikum. Seorang mahasiswa atau calon guru pun harus memiliki kepribadian yang dewasa salah satunya memiliki etos kerja yang tinggi dan tanggung jawab. Etos kerja suatu kepribadian yang dapat dilihat ketika mahasiswa atau calon guru dapat menerapkan kedisiplinan dan kerapihan dalam melaksanaan pekerjaan atau tugasnya. Sehingga, pada saat mahasiswa menjadi calon guru dapat mengaplikan langsung terhadap segala tanggungjawabnya sebagai pengajar yang dapat mencerminkan kedisiplinan dan kerapihan pada peserta didik dalam setiap aktivitas belajar mengajar berlangsung. Calon guru yang memiliki kompetensi kepribadian yang berwibawa dan memiliki etos kerja tinggi lalu didukung dengan selalu bertindak dalam kebermanfaatan. Sehingga, dalam penerapannya mengajar peserta didik, ketika melakukan suatu praktikum pada matapelajaran geografi memiliki kedisiplinan waktu dan penggunaan bahan serta alat yang memang benar-benar digunakan saja. Dengan demikian, secara tidak langsung mahasiswa sebagai calon guru dapat menerapkan pemanfaatkan waktu dan kegiatan dengan disiplin.

Jurnal Geografi Vol 12 No. 01 - 2020
3. Variabel X3 (Penilaian Kinerja Presentasi) dengan Variabel Y (Kompetensi Kepribadian)

Berdasarkan hasil penelitian pada hasil uji korelasi, kontribusi penilaian kinerja presentasi terhadap pembentukan kompetensi kepribadian calon guru sebesar $10,8 \%$. Setiap calon guru yang mendapatkan penilaian Kinerja Presentasi, akan berkontribusi terhadap pembentukan kompetensi calon guru. Sesuai dengan hasil penelitian oleh Iskandar Agung (2014) yaitu, urutan peringkat indikator dalam kompetensi kepribadian, adalah kepemimpinan, etos kerja, pengembangan diri berkelanjutan, dan orientasi prestasi. Dilihat dari hasil korelasi yang hanya 10,8 \% saja dari kegiatan penilaian presentasi pada PKL terhadap pembentukan kompetensi kepribadian calon guru, namun penyampain kinerja presentasi dengan baik berdampak positif apabila diterapkan oleh mahasiswa pendidikan geografi ketika menjadi calon guru kelak. Kinerja Presentasi/penyajian lisan/ketrampilan berbicara, berdiskusi, pemecahan masalah dalam kelompok menentukan bagaimana bisa terbentuk suatu kompetensi kepribadian pada calon guru. Kepandaian berbicara seorang guru di depan kelas, sangat berdampak positif bagi peserta didik. Sehingga, peserta didik tidak menganggap sang guru berbicara omong kosong belaka dan peserta didik dengan mudah merangkum pembelajaran dari pembicaraan guru secara langsung. Dengan demikian, gurupun harus tetap bertanggung jawab atas apa yang ia sampaikan, sehingga penyampaian tidak dapat dilakukan dengan sembarang, namun dengan pengetahuan dan penyampaian secara ilmiah. Proses penilaian presentasi pada PKL dapat menggambarkan bagaimana mahasiswa calon guru tersebut menyampaikan presentasi dengan apik dan tegas sehingga baik intonasi, gestur tubuh, penggunaan bahasa dan penyampaian secara ilmiah dapat diterima oleh pendengar atau peserta 
didik dengan jelas. Matapelajaran geografi merupakan sebagai ilmu bumi dan sekitarnya yang sering kita lihat. Ketika sorang guru dengan pandai menyampaikan materi dengan contoh penerapan langsung pada dunia nyata, peserta didik pun akan mudah menganalisis dan menyerap contoh yang disampaikan oleh guru, sehingga proses belajar mengajar akan lebih nyata lagi. Maka dari itu, pada penilai presentasi yang didapat oleh mahasiswa Pendidikan Geografi sebagai calon guru ini dapat sekali dikaitkan dengan indikator kepribadian calon guru yang nantinya akan memimpin jalannya proses kegiatan belajar mengajar di kelas dengan orientasi dengan baik.

4. Variabel X4 (Penilaian Proyek) dengan Variabel Y (Kompetensi Kepribadian)

Berdasarkan hasil penelitian pada hasil uji korelasi, kontribusi penilaian proyek terhadap pembentukan kompetensi kepribadian calon guru sebesar 33,2\%. Setiap calon guru yang mendapatkan penilaian proyek, akan berkontribusi terhadap pembentukan kompetensi calon guru. Hal ini sesuai dengan penelitian oleh Sugeng Mardiyono (2006) ada dua faktor utama yang perlu mendapat perhatian dalam peningkatan kualitas calon guru lewat KKNPPL tersebut adalah pemberdayaan dan pembudayaan. Faktor pemberdayaan mencakup peningkatan kemampuan dan pengelolaan sumber daya sehingga memiliki relevansi tinggi dengan manajemen dan administrasi yang tangguh. Sedangkan faktor pembudayaan meliputi kemauan, etos kerja, dan keberlanjutan (sustainability) program peningkatan kualitas calon guru. Perencanaan, pengumpulan data, pengorganisasian, pengolahan, analisis, dan penyajian data pada PKL program studi Pendidikan Geografi berpengaruh terhadap peningkatan kualitas calon guru. Kegiatan penilaian proyek pada PKL yang dilakukan oleh mahasiswa Pendidikan Geografi sebagai calon guru merupakan kegiatan pada saat PKL berlangsung yaitu meliputi kegiatan pengumpulan data, pengolahan data, dan pelaporan hasil data yang di dapat. Pengumpulan data yang sesuai dengan tujuan dan pengambilan sumber data yang jelas, pengolahan data dengan rapih dan argumentasi yang kuat, serta membuat pelaporan yang sistematis dan lengkap, dapat menggambarkan apabila dikaitkan dengan indikator kompetensi kepribadian mahasiswa calon guru memiliki kepribadian yang dewasa memiliki etos kerja tinggi, maka mahasiswa calon guru. Administrasi dan manajemen yang diterapkan pada kurikulum ini merupakan tugas tenaga pendidik sebagai calon guru, sehingga tenaga pendidik dalam kegiatan belajar mengajar berpedoman terhadap rancangan pembelajaran, sehingga proses kegiatan belajar mengajar lebih terstruktur. Kebiasaan dalam pengerjaan proyek yang rapih dan jelas tentunya akan berdampak pada mahasiswa sebagai calon guru yang memiliki etos kerja yang tinggi dan proseional dalam bekerja.

5. Variabel X5 (Penilaian Portofolio) dengan Variabel Y (Kompetensi Kepribadian)

Berdasarkan hasil penelitian pada hasil uji korelasi, kontribusi penilaian portofolio terhadap pembentukan kompetensi kepribadian calon guru sebesar $13,7 \%$. Setiap calon guru yang mendapatkan penilaian portofolio, hanya akan berkontribusi kecil terhadap pembentukan kompetensi calon guru. Portofolio merupakan tugas-tugas yang dikerjakan mahasiswa, laporan kegiatan mahasiswa, catatan hasil observasi, dan catatan hasil wawancara. Hal ini merupakan salah satu penilaian yang dilakukan selama PKL yaitu sebanyak tigapuluh persen (30\%). Namun, adanya perbedaan dalam produk yang dihasilkan setiap jenis PKL atau angkatan, sehingga penilaian portofolio tidak bisa disamakan penilaiannya. Penilaian portofolio bisa saja berpengaruh terhadap pembentukan kompetensi kepribadian, karena dalam penilaian portofolio terdapat 
tugas-tugas hasil observasi dan laporanlaporan kegiatan wawancara maupun dokumentasi pada kegiatan PKL berlangsung. Sehingga mahasiswa calon guru yang mengerjakan tugas-tugas dan laporan tepat waktu dan dikumpulkan secara rapih serta sesuai dengan ketentuan yang ada pada RPS, apabila dikaitkan dengan kompetensi kepribadian calon guru menunjukan kepribadian yang dewasa dan arif yaitu memiliki etos kerja yang tinggi dan bertindak yang bermanfaat.Dengan demikian, mahasiswa pendidikan geografi sebagai calon guru dapat menerapkan kepada peserta didik bagaimana cara melakuakan kinerja portofolio yang baik, sehingga tidak ada perbedaan tugas dan nilai yang didapat oleh peserta didik.

\section{KESIMPULAN}

Berdasarkan hasil penjelasan pembahasan, maka dapat disimpulkan sebagai berikut: pertama, pada Variabel Penilaian Sikap (X1), Kinerja Alat (X2), Kinerja Presentasi (X3), dan Portofolio (X5), dengan Variabel Kompetensi Kepribadian (Y), menyatakan bahwa variabel Penilaian Proyek (X4) memiliki kekuatan hubungan lebih besar dengan variabel Kepribadian (Y) dibanding penilaian lainnya. Kedua, pada Penilaian Sikap (X1) dan Portofolio (X5) berbanding terbalik hubungannya dengan Kompetensi Kepribadian (Y), karena sikap terbentuk akibat dari dampak pembelajaran secara tidak langsung (Nurtu-rant Effect) dan penilaian portofolio adanya perbedaan dalam produk yang dihasilkan setiap jenis PKL atau angkatan, sehingga penilaian portofolio tidak bisa disamakan penilaiannya. Sehingga, secara keseluruhan dapat disimpulkan adanya hubungan antara kompetensi kepribadian dengan penilaian proyek pada praktik kuliah lapangan yang dilakukan mahasiswa atau calon guru di Program Studi Pendidikan Geografi
Fakultas Ilmu Sosial Universitas Negeri Jakarta.

\section{SARAN}

Berdasarkan kesimpulan di atas, peneliti mengajukan saran bahwa penilaian sikap tidak dapat digunakan karana terbentuk sebagai efek samping dari setiap kegiatan secara tidak langsung dan penilian portofolio direvisi karena setiap angkatan menghasilkan produk hasil yang berbedabeda. Dengan demikian, perlu diperhatikan kembali mengenai penilaian praktik kuliah lapangan pada mahasiswa program studi pendidikan geografi sebagai calon guru sehingga dapat memenuhi capaian pembelajaran lulusan PKL pada Rencana Pembelajaran Semester praktik kuliah lapangan dari berbagai ranah yang perlu dicapai.

\section{DAFTAR PUSTAKA}

Agung, I. (2014). Kajian pengaruh kompetensi kepribadian dan sosial terhadap kinerja guru. Jurnal Ilmiah VISI, 9(2), 83-92.

Al-Makassary, A. (2014). Indikator Kompetensi Guru. [online], http://www.ejurnal.com/2014/02/ind ikator-kompetensi-guru.html, [diakses pada tanggal 30 April 2018]

Buku Panduan Akademik tahun 2016/2017 Fakultas Ilmu Sosial Universitas Negeri Jakarta.

Hall, C., \& Lindzey, G. (2005). Teori-Teori Holistik (Organismik-Fenomenologis), terj. Yustinus, judul asli "Theories of Personality" (Yogyakarta: Kanisius, 1993).

Hamalik, O. (2008). Kurikulum pembelajaran. Jakarta: Sinar Grafika.

Hayati, Sri. (2005). Pedoman Praktik Kerja Lapangan Jurusan Pendidikan Geografi. Bandung: Universitas Pendidikan Indonesia 
Husamah, H. (2013). PEMBELAJARAN LUAR KELAS (OUTDOOR LEARNING). Research Report.

Indonesia, P. R. (2003). Undang-undang Republik Indonesia nomor 20 tahun 2003 tentang sistem pendidikan nasional. Jakarta: Pemerintah Republik Indonesia.

Indonesia, P. R. (2003). Undang-undang Republik Indonesia nomor 20 tahun 2003 tentang sistem pendidikan nasional. Jakarta: Pemerintah Republik Indonesia.

Indonesia, P. R. (2005). Peraturan Pemerintah Republik Indonesia nomor 19 tahun 2005 tentang standar nasional pendidikan. Departemen Pendidikan Nasional Republik Indonesia.

Indonesia. (2010). Peraturan pemerintah nomor 17 tahun 2010 tentang pengelolaan dan penyelenggaraan pendidikan. Pustaka Timur.

Janawi. (2007). Kompetensi Guru: Citra Guru Profesional. Bangka Belitung: Shiddiq Press.

Joyce, B., Weil, M., \& Calhoun, E. (2009). Models of teaching: Model-model pengajaran. Yogyakarta: Pustaka Pelajar.

Kunandar. (2014). Penilaian Autentik (Penilian Hasil Belajar Peserta Didik Berdasarkan Kurikulum 2013), Rajagrafindo Persada, Bandung

Mahanal, S.2007. Portofolio sebagai Asesment Otentik. (online), (http://lubisgrafura.wordpress.com/2 007/09/07/ portofolio-sebagaiasesmen-otentik/) [diakses pada tanggal 20 September 2018]

Mardiyono, S. (2006). Praktik Pengalaman Lapangan Terpadu dalam Peningkatan Kualitas Calon Guru. (skripsi) Yogyakarta: Universitas Negeri Yogyakarta

Martono, N. (2015). Metode penelitian sosial: konsep-konsep kunci. Jakarta: $\quad$ PT RajaGrafindo Persada.
Mulyantari. (2005). Kuliah Kerja Lapangan (KKL) I Geografi Sebagai Salah Satu Metode Pembelajaran Kontekstual dan Pengaruhnya Terhadap Prestasi Belajar Mahasiswa Pendidikan Geograf. (skripsi). Jurusan Geografi. FIS. UNES. Semarang

Nitko, Anthony J. 1996. Educational Assessment of Student. New Jersey: Prentice Hall. [online]https://www.academia.edu/30 243818/ Evaluasi Kinerja Anasir Kognitif Dan Pengetahuan Awal, [diakses pada tanggal 12 Juli 2018]

Olfos, R., \& Zulantay, H. (2007). Reliability and validity of authentic assessment in a web based course. Journal of Educational Technology \& Society, 10(4), 156-173.

Rencana Pembelajaran Semester Mata Kuliah Praktik Kuliah Lapangan Program Studi Pendidikan Geografi Fakultas Ilmu Sosial Universitas Negeri Jakarta tahun 2017

Setyawati, Sriadi. (2010). Panduan Pelaksanaan Praktik Kuliah Lapangan Geografi Terpadu. Yogyakarta: Universitas Negeri Yogyakarta

Silaen, S. (2013). Metodologi penelitian sosial untuk penulisan skripsi dan tesis. Penerbit IN MEDIA Jakarta.

Sudaryono. (2012). Dasar-dasar evaluasi pembelajaran. Graha Ilmu.

Sugiyono. (2016). Metode Penelitian: Kuantitatif, Kualitatif dan RED. Bandung :Alfabeta.

Sukardi, P. D. (2003). Metodologi Penelitian Pendidikan. Jakarta: Bumi Aksara.

Sumaatmadja, N. (1984). Metodologi Pengajaran Ilmu Pengetahuan Sosial (IPS). Alumni.

Suryabrata, S. (2008). Psikologi kepribadian (Cetakan keenam belas). Jakarta: PT Raja Grafindo Persada.

Ulum, Miftahul. (2016). Pengaruh Praktik Kerja Lapangan terhadap Minat Berwirausaha pada Mahasiswa Program Studi Pendidikan Teknik Mesin Universitas 
Negeri Semarang. (skripsi). Semarang: Universitas Negeri Semarang

Vera, A. (2012). Metode Mengajar Anak di Luar Kelas (Outdoor Study). Yogyakarta: Divapress.
Yususf, M. (2015). Asesmen dan Evaluasi Pendidikan Pilar: Penyedia Informasi dan Kegiatan Pengendalian Mutu Pendidikan. Jakarta: Prenamedia Group.

Zuldafrial, et al. (2014). Profesi Kependidikan Guru.Yogyakarta: Media Perkasa 